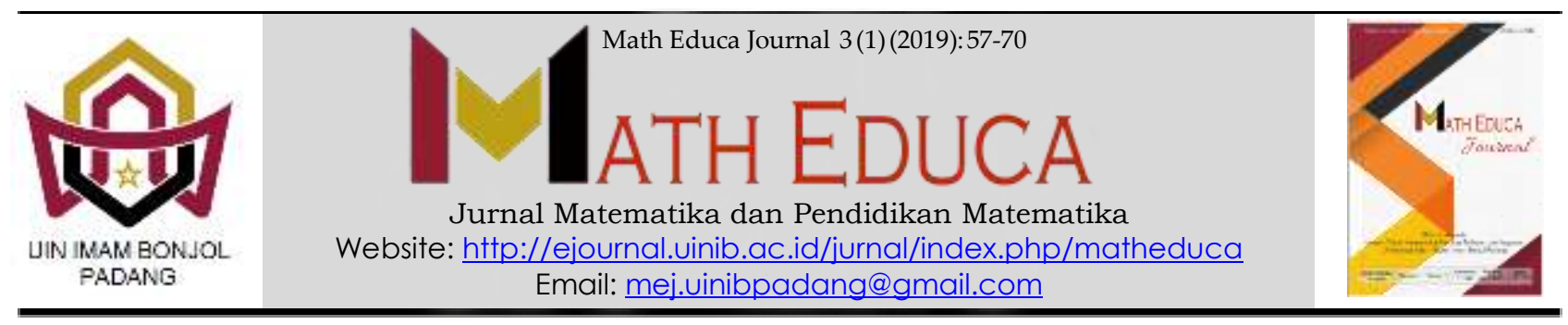

\title{
ANALISIS KEMAMPUAN PEMECAHAN MASALAH PESERTA DIDIK YANG BELAJAR DENGAN STRATEGI PROBLEM SOLVING BERDASARKAN LANGKAH POLYA
}

\author{
Wina Fajriah \\ SMP Kartika I - 6 Kota Padang \\ Email: winafajriah90@gmail.com
}

Received: January 2019; Accepted: March 2019; Published: April 2019

\begin{abstract}
Abstrak
Tujuan penelitian ini menganalisis kemampuan pemecahan masalah peserta didik kelas VIII SMP Kartika I-6 Kota Padang yang belajar dengan strategi pembelajaran problem solving berdasarkan langkahlangkah Polya dalam menyelesaikan soal cerita. Jenis penelitian ini adalah deskriptif dengan pendekatan kualitatif.Subjek penelitian ini adalah peserta didik kelas VIII. Setelah diterapkan strategi pembelajaran problem solving, peserta didik diberikan tes kemampuan pemecahan masalah kemudian hasilnya dianalisis dengan langkah-langkah Polya. Hasil tes membedakan peserta didik dalam tiga tingkat kemampuan pemecahan masalah yaitu level tinggi $25 \%$, sedang 50\% dan rendah $25 \%$. Berdasarkan indikator pemecahan masalah Polya, diketahui bahwa kemampuan peserta didik dalam : memahami masalah dan menyusun rencana masuk dalam kategori tinggi, sedangkan untuk melaksanakan rencana sedang serta memeriksa jawaban kembali rendah.
\end{abstract}

Kata kunci: Problem solving, kemampuan pemecahan masalah, langkah-langkah Polya

\begin{abstract}
The purpose of this study was to analyze the problem solving abilities of SMP Kartika I-6 grade VIII students, who learn with problem solving strategies based on Polya steps in solving story problems. This research is descriptive with a qualitative approach. The subject of this study was class VIII ${ }_{1}$ student. After problem solving learning strategy are applied, given test problem solving ability in participants and the results are analyzed based on the steps of pattern. Test results raising students in three levels of problem solving skills, namely a high level of $25 \%$, medium $50 \%$, lower $25 \%$. Based on the indicator of problem solving, it is known that the ability of students in understanding problems and arranging settlement plans is in the high category, while in implementing the completion plan it is categorized as being moderate and checking the answers back at a low level.
\end{abstract}

\footnotetext{
${ }^{*}$ Corresponding author.

Peer review under responsibility UIN Imam Bonjol Padang.

(C) 2019 UIN Imam Bonjol Padang. All rights reserved. 


\section{PENDAHULUAN}

Kemampuan pemecahan masalah merupakan kemampuan yang harus dimiliki setiap manusia yang bisa diperoleh dalam belajar matematika. Sepriyanti (2017:2) menyatakan bahwa matematika merupakan suatu disiplin ilmu yang timbul karena pikiranpikiran manusia yang berhubungan dengan ide, proses, dan penalaran. Sepriyanti (2016:2) tujuan pembelajaran matematika adalah untuk mengasah kemampuan bernalar, berfikir logis, dan sistematik dan agar peserta didik memiliki kemampuan pemecahan masalah, Pemecahan masalah lebih mengutamakan proses dan strategi yang dilakukan peserta didik dalam penyelesaian masalah dari pada hanya sekedar hasilnya, maka dari itu akan berdampak positif pada pemahaman konsep dan kreativitas peserta didik.

Kegiatan-kegiatan yang diklarifikasi sebagai pemecahan masalah dalam matematika diantaranya menyelesaikan soal cerita dalam buku teks. Sepriyanti (2015:106) mahasiswa kurang mampu dalam menyelesaikan soal berbentuk cerita (soal tidak rutin), yaitu memecahkan masalah matematika yang terkait dengan dunia nyata.

Kemampuan pemecahan masalah adalah suatu tindakan untuk menyelesaikan masalah atau proses yang menggunakan kekuatan dan manfaat matematika dalam menyelesaikan masalah, yang juga merupakan metode penemuan solusi melalui tahap-tahap pemecahan masalah.

Adapun beberapa manfaat yang akan diperoleh oleh peserta didik melalui pemecahan masalah menurut Murdiana (2015:1) yaitu:

1. Meningkatkan pemahaman peserta didik terhadap materi yang telah dipelajari.

2. Meningkatkan kemampuan peserta didik menggunakan konsep-konsep yang telah dipelajari dalam berbagai situsi real.

3. Meningkatkan kemampuan analisis dan sintesis.

4. Meningkatkan kecerdasan bahasa dan logika .

5. Meningkatkan transfer pengetahuan.

Keragaman masalah yang berhubungan dengan kemampuan pemecahan masalah dialami peserta didik kelas VIII SMP Kartika I-6 Kota Padang terutama dalam menyelesaikan masalah dalam bentuk soal cerita. Berdasarkan wawancara dengan peserta didik diperoleh informasi bahwa peserta didik mengalami kesulitan dalam menterjemahkan bahasa soal ke bahasa matematika atau pemodelan matematika dan hal ini masih menjadi permasalahan yang terus dihadapi pendidik.

Selama ini pendidik belum pernah melakukan analisis mendalam terhadap kemampuan pemecahan masalah peserta didik. Pendidik belum mengetahui tingkat 
kemampuan pemecahan masalah peserta didik. Oleh sebab itu diperlukan analisis lebih mendalam pada kemampuan pemecahan masalah peserta didik, serta strategi pembelajaran yang tepat dan dapat membuat kemampuan pemecahan masalah peserta didik meningkat.

Salah satu upaya yang digunakan untuk menyelesaikan masalah matematika adalah dengan strategi pembelajaran problem solving. Problem solving secara denovatif adalah pemecahan masalah, sebagai sebuah strategi pembelajaran, Problem solving adalah sebuah cara membelajarkan peserta didik yang difokuskan pada suatu masalah (problem) atau isu untuk dianalisis dan dipecahkan sehingga diperoleh suatu kesimpulan.

Pristiwanto (2016:129), Adapun langkah-langkah tersebut adalah :

1. Merumuskan masalah,

2. Menelaah masalah,

3. Merumuskan hipotesis,

4. Mengumpulkan data,

5. Pembuktian hipotesis,

6. Menentukan pilihan penyelesaian.

Setelah dilakukan pembelajaran dengan strategi problem solving, untuk mengetahui kemampuan pemecahan masalah peserta didik dilakukan analisis dengan menerapkan langkah-langkah pemecahan masalah Polya. Dengan pemecahan masalah Polya, langkah-langkah dalam memecahkan masalah matematika akan lebih singkat.
Menurut Polya dalam Suherman, (2003:84) terdapat empat langkah dalam memecahkan masalah, yang mana semua langkah-langkah pada strategi pembelajaran problem solving telah terangkum dalam empat langkah Polya tersebut. Adapun empat langkah tersebut yaitu :

a) Memahami masalah,

b) Menyusun rencana,

c) Melaksanakan rencana,

d) Mengecek kembali.

Untuk itu yang menjadi tujuan penelitian ini adalah untuk mendeskripsikan dan menganalisis kemampuan pemecahan masalah peserta didik yang belajar dengan strategi pembelajaran problem solving berdasarkan langkah-langkah Polya dalam menyelesaikan soal cerita.

\section{METODE PENELITIAN}

Sesuai dengan masalah yang diteliti, maka penelitian ini adalah penelitian kualitatif deskriptif. Dikatakan penelitian deskriptif karena peneliti melakukan analisis hanya sampai taraf deskripsi, yaitu menganalisis dan menyajikan fakta secara sistematis. Metode kualitatif menunjuk kepada prosedur-prosedur riset yang menghasilkan data kualitatif, seperti : ungkapan atau catatan orang atau tingkah laku orang. Penelitian kualitatif sebagai prosedur penelitian yang menghasilkan data deskriptif berupa kata-kata tertulis atau lisan 
dari orang-orang dan pelaku yang diamati, Ulpa (2014:35). Proses yang diamati adalah kegiatan peserta didik pada saat menyelesaikan masalah matematika pada materi Sistem Persamaan Linear Dua Variabel.

Penelitian ini dilakukan di SMP Kartika I-6 Kota Padang, pada bulan November 2018 sampai selesai. Subjek penelitian ini adalah peserta didik kelas VIII.1 SMP Kartika I-6 Kota Padang yang rendahnya kemampuan pemecahan masalah peserta didik yang terdaftar pada semester 1 Tahun Ajaran 2018/2019. Subjek penelitian yang dijadikan sumber data kualitatif terdiri dari 8 peserta didik yang mempunyai kemampuan pemecahan masalah yang berbeda. Subjek penelitian ini terdiri dari 2 peserta didik dari kelompok tingkat tinggi, 4 peserta didik dari kelompok tingkat menengah, dan 2 peserta didik dari kelompok tingkat rendah.

Arikunto (1993:296) langkah-langkah yang digunakan dalam pengelompokan peserta didik berdasarkan kemampuannya adalah sebagai berikut :

1. Menjumlahkan skor setiap peserta didik.

2. Mencari nilai rata-rata (mean) dan simpangan baku (standar deviasi).

Rata-rata peserta didk dihitung dengan menggunakan rumus sebagai berikut :

$$
X=\frac{\sum_{i=1}^{n} x_{i}}{n}
$$

Keterangan :

$\bar{X}=$ rata-rata skor peserta didik

$\mathrm{n}=$ banyak peserta didik

$x i=$ data ke $i=1,2,3, \ldots$

Untuk simpangan baku di hitung dengan rumus :

$$
S D=\sqrt{\frac{n \sum_{i=1}^{n} x_{i}^{2}-\left(\sum_{i=1}^{n} x_{i}\right)^{2}}{n(n-1)}}
$$

Keterangan :

$\mathrm{SD}=$ standar deviasi

3. Menentukan Batas-batas Kelompok

Secara umum penentuan-penentuan batas-batas kelompok dapat dilihat dari Tabel 1:

Tabel 1. Kriteria Pengelompokan Peserta Didik

\begin{tabular}{cc}
\hline Skor $(\mathrm{s})$ & Kelompok \\
\hline$S \geq(\bar{x}+S D)$ & Atas \\
$(\bar{x}-S D)<S<(\bar{x}+S D)$ & Menengah \\
$S \leq(\bar{x}-S D)$ & Bawah \\
\hline Sumber: Arikunto $(1993: 296)$ &
\end{tabular}

Sumber : Arikunto (1993:296)

Menurut Dina (2014:117), populasi dalam penelitian mempunyai sifat yang umum berupa benda alam atau makhluk hidup. Selain itu populasi tidak hanya soal jumlah objek dan subjek yang dipelajari dan diteliti, tetapi populasi harus menunjukkan sifat dan semua karakter yang ada dalam subjek dan objek penelitian. Populasi dalam penelitian ini adalah seluruh peserta didik kelas VIII SMP Kartika I-6 Kota Padang yang terdaftar pada semester ganjil tahun ajaran 2018/2019 sebanyak 3 kelas yang terdiri dari 95 orang. Untuk lebih jelasnya dapat dilihat pada Tabel 2. 
Tabel 2. Kelas VIII SMP Kartika I-6 Kota Padang Tahun Pelajaran 2018/2019

\begin{tabular}{cc}
\hline Kelas & Jumlah Peserta Didik \\
\hline VIII.1 & 32 \\
VIII.2 & 31 \\
VIII.3 & 32 \\
\hline
\end{tabular}

Sumber : Guru mata pelajaran matematika

Pemilihan kelas sampel yang dilakukan adalah dengan menggunakan teknik purposive sampling. Purposive sampling berbeda dengan cara-cara penentuan sampel yang lain, penentuan sumber informasi secara purposive dilandasi tujuan atau pertimbangan tertentu terlebih dahulu. Tujuannya adalah pengambil kelas sampel yang kemampuan pemecahan masalah peserta didik rendah. Oleh karena itu, pengambilan sumber informasi didasarkan pada maksud yang telah ditetapkan sebelumnya, dikemukakan oleh Riduwan (2010:63). Kelas yang dijadikan sampel adalah kelas yang memiliki persentase terendah dari tes awal peserta didik kelas VIII SMP Kartika I-6 Kota Padang yaitu kelas VIII.1.

Variabel penelitian merupakan faktor yang mempengaruhi dalam penelitian, sebab variabel adalah objek pengamatan dalam penelitian. Sesuai dengan tujuan penelitian, maka variabel yang akan diteliti adalah kemampuan pemecahan masalah peserta didik berdasarkan langkah-langkah polya dalam menyelesaikan soal cerita SPLDV.

Data yang digunakan dalam penelitian ini adalah data primer dan data sekunder. Data primer diperoleh dari hasil kerja atau lembar jawaban peserta didik yang telah diberi skor oleh pendidik, sedangkan data sekunder adalah nilai ulangan harian semester 1 matematika kelas VIII.1 SMP Kartika I-6 Kota Padang Tahun Ajaran 2018/2019.

Instrumen penelitian adalah alat bantu yang dipilih dan digunakan oleh peneliti dalam kegiatannya mengumpulkan kegiatan tersebut menjadi sistematis, Latif (2016:210). Pada penelitian ini, instrumen yang digunakan adalah tes tertulis. Tes dalam penelitian ini adalah tes tertulis yang bertujuan untuk mengetahui kemampuan pemecahan masalah peserta didik berdasarkan langkah-langkah Polya.

Untuk memperoleh data dalam penelitian ini digunakan dua teknik pengumpulan data yaitu:

1. Tes

Arikunto, (2001:50) Tes merupakan alat atau prosedur yang digunakan untuk mengetahui atau mengukur sesuatu dalam suasana, dengan cara dan aturan-aturan yang sudah ditentukan. Tes yang digunakan dalam penelitian ini adalah tes berbentuk uraian yang disusun dan dikembangkan oleh pendidik sesuai dengan indikator pembelajaran.

2. Dokumentasi

Sunaendar (2017:88), dokumentasi adalah sebuah cara yang 
dilakukan untuk menyediakan berbagai macam dokumen, salah satu caranya adalah dengan menggunakan bukti akurat dari pencatatan sumbersumber informasi. Dokumentasi merupakan catatan peristiwa yang sudah berlalu. Dokumentasi bisa berbentuk tulisan, gambar atau karyakarya monumental dari seseorang. Dokumentasi yang berbentuk tulisan misalnya sejarah kehidupan, cerita, biografi, peraturan dan kebijakan. Dokumentasi berbentuk gambar misalnya foto, gambar hidup.

Dalam penelitian ini dokumentasinya berupa kertas lembar jawaban peserta didik, foto saat belajar dan foto saat ujian peserta didik SMP Kartika I-6 Kota Padang Tahun Ajaran 2018/2019.

Prosedur penelitian yang dilakukan dibagi atas tiga tahap, yaitu :

1) Tahap persiapan. Tahap ini terdiri dari: mempersiapkan materi penelitian, menentukan jadwal, menentukan sampel, mempersiapkan RPP, membuat kisi-kisi dan soal, memvalidasi soal, melaksanakan uji coba.

2) Tahap pelaksanaan. Dalam tahap ini, pelaksanaan penelitian di kelas VIII.1 dilakukan dengan menggunakan strategi pembelajaran problem solving kemudian diberikan tes.
3) Tahap penyelesaian. Pada tahap ini, hasil tes di analisis dengan langkah Polya dan diberi skor untuk mengetahui tingkat kemampuan peserta didik.

Tahap reduksi data dalam penelitian ini adalah :

1. Mengoreksi dan memberi skor lembar jawaban peserta didik dan menentukan peserta didik yang dijadikan subjek penelitian.

2. Menganalisis lembar jawaban subjek penelitian dengan cara membandingkannya dengan penyelesaian berdasarkan langkah Polya, sehingga di ketahui tingkat kemampuan pemecahan masalah peserta didik berdasarkan pemecahan masalah Polya dalam menjawab soal berbentuk uraian pada materi SPLDV.

\section{HASIL DAN PEMBAHASAN}

Berdasarkan hasil tes kemampuan pemecahan masalah, peserta didik dikategorikan menjadi 3 kelompok yaitu kelompok peserta didik berkemampuan tinggi, kelompok peserta didik berkemampuan menengah dan kelompok peserta didik berkemampuan bawah.

Adapun kriteria pengelompokan peserta didik berdasarkan hasil tes dapat di lihat pada Tabel 3. 
Tabel 3. Kriteria Pengelompokan Kemampuan Pemecahan Masalah Peserta Didik

\begin{tabular}{cllc}
\hline No & Kelompok & Kriteria & $\begin{array}{c}\text { Jumlah } \\
\text { Peserta } \\
\text { Didik }\end{array}$ \\
\hline 1 & Tinggi & $\mathrm{S} \geq 85$ & 8 \\
2 & Menengah & $53<\mathrm{S}<85$ & 16 \\
3 & Bawah & $\mathrm{S} \leq 53$ & 8 \\
\hline \multicolumn{3}{c}{ Jumlah } & 32 \\
\hline \multicolumn{4}{c}{}
\end{tabular}

Berdasarkan Tabel 3 dari 32 orang peserta didik yang diteliti, jumlah peserta didik yang memiliki kemampuan pemecahan masalah tinggi ada 25\%, peserta didik kelompok menengah ada 50\% dan peserta didik kelompok bawah ada $25 \%$.

Data tes kemampuan pemecahan masalah terdiri dari enam soal yang mengandung empat indikator secara rinci dapat dilihat melalui masing-masing persentase tiap indikator kemampuan pemecahan masalah seperti pada Tabel 4:

Tabel 4. Persentase Pencapaian Indikator Kemampuan Pemecahan Masalah

\begin{tabular}{|c|l|c|}
\hline No & \multicolumn{1}{|c|}{ Indikator } & Rata-rata \\
\hline 1. & Memahami Masalah & $89,68 \%$ \\
\hline 2. & $\begin{array}{l}\text { Merencanakan } \\
\text { Penyelesaian Masalah }\end{array}$ & $89,88 \%$ \\
\hline 3. & $\begin{array}{l}\text { Melaksanakan } \\
\text { Perencanaan } \\
\text { Penyelesaian }\end{array}$ & $66,52 \%$ \\
\hline 4. & Pengecekan Kembali & $30,36 \%$ \\
\hline
\end{tabular}

Berdasarkan Tabel 4 dari 32 peserta didik dan persentase kemampuan pemecahan masalah terendah yaitu pada tahap pengecekan kembali dan persentase terendahnya pada tahap merencanakan dan melakasanakan penyelesaian. Sementara kemampuan merencanakan dan melaksanakan rencana penyelesaian sama.

Persentase indikator kemampuan pemecahan masalah masing-masing tingkat kemampuan pemecahan masalah peserta didik dapat dilihat pada:

Tabel 5. Persentase Pencapaian Indikator Masing-masing Tingkat Kemampuan

\begin{tabular}{ccccc}
\hline \multirow{2}{*}{ No } & \multirow{2}{*}{ Indikator } & \multicolumn{3}{c}{ Tingkat Kemampuan } \\
& & T & M & B \\
\hline 1 & $\begin{array}{l}\text { Memahami } \\
\text { Masalah }\end{array}$ & 97,6: $90,87 \%$ & $79,36 \%$ \\
2 & $\begin{array}{l}\text { Merencanakan } \\
\text { Penyelesaian }\end{array}$ & 100\%, 91,07\% & $77,38 \%$ \\
3 & $\begin{array}{l}\text { Melaksanakan } \\
\text { Perencanaan }\end{array}$ & 98,8: 74,40\% & $36,31 \%$ \\
4 & $\begin{array}{l}\text { Pengecekan } \\
\text { Kembali }\end{array}$ & $59,5: 25 \%$ & $11,90 \%$ \\
\hline
\end{tabular}

Berdasarkan Tabel 5 maka dapat disimpulkan bahwa kemampuan terendah peserta didik dalam langkah Polya yaitu pada tahap pengecekan jawaban kembali.

Dari hasil analisis data yang dilakukan diperoleh :

1. Peserta didik dengan tingkat kemampuan tinggi.

a. Memahami masalah

Pada langkah ini, kedua subjek tidak mengalami kesulitan dalam menentukan kecukupan syarat yang diperlukan untuk menyelesaikan permasalahan.

b. Membuat rencana pemecahan masalah Pada langkah ini, kedua subjek mampu menjelaskan hubungan antara yang diketahui dengan yang ditanyakan pada soal secara tepat dengan rinci. 
c. Melaksanakan rencana pemecahan masalah

Pada tahap ini, kedua subjek melaksanakan proses perhitungan sesuai dengan rencana yang telah disusunnya. Namun subjek 2 sedikit terkendala pada proses penyelesaian soal nomor dua, yaitu pada tahap menggambarkan grafik.

d. Memeriksa kembali

Pada tahap ini, untuk beberapa soal kedua subjek terkendala dalam melakukannya.

Sebagai contoh subjek 2 pada soal nomor 5:

Umur Sani 7 tahun lebih tua dari Ari, sedangkan jumlah umur mereka adalah 43 tahun. Buatlah model matematikanya dan tentukan umur mereka masing-masing dengan metode subtitusi!

Dalam memahami masalah pada nomor lima dapat dilihat pada Gambar 1

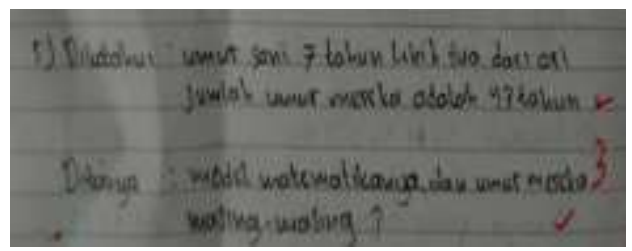

Gambar 1. Jawaban S2 nomor 5 tahap 1

Berdasarkan Gambar 1 SM menuliskan apa yang diketahui dan apa yang ditanya pada soal. Dapat diketahui SM sudah mengerjakan tahap 1 dengan tepat.
Pada tahap merencanakan penyelesaian dapat dilihat pada Gambar 2 berikut :

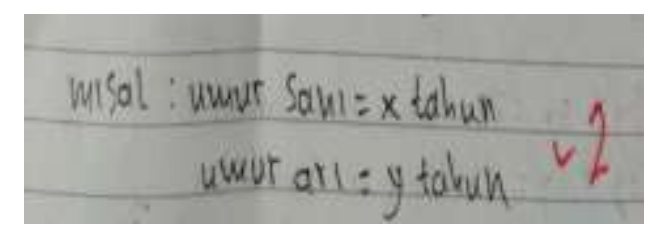

Gambar 2. Jawaban S2 nomor 5 tahap 2

Berdasarkan Gambar 2. SM menuliskan rencana dengan memisalkan umur Sani dan Ari dengan variabel $x$ dan $y$. Namun SM tidak menentukan persamaan satu dan persamaan dua, serta langkah apa yang akan dilakukan selanjutnya. Seperti mensubtitusi nilai x kepersamaan 2 . Dengan demikian SM sudah mengerjakan tahap 2 namun belum lengkap.

Tahap melaksanakan rencana dapat dilihat pada Gambar 3 berikut :

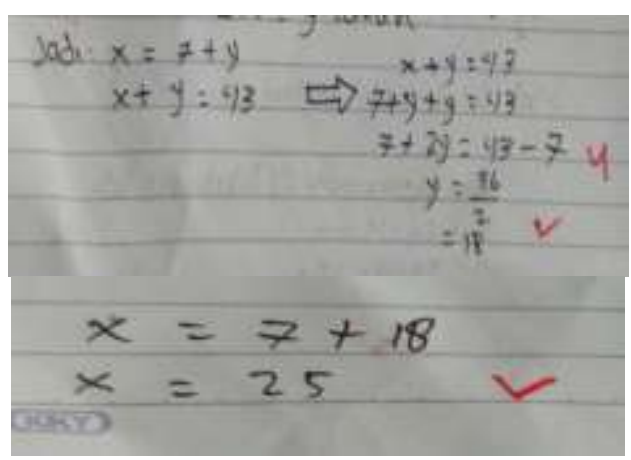

Gambar 3. Jawaban S2 nomor 5 tahap 3

Berdasarkan Gambar di atas dapat dilihat bahwa SM mensubtitusikan nilai $\mathrm{x}=7+\mathrm{y}$ pada persamaan dua, sehingga dapat di tentukan umur keduanya. Dengan demikian dapat diketahui SM sudah 
mengerjakan tahap 3 dengan benar dan tepat.

Pada tahap pengecekan kembali dapat dilihat pada gambar 4 berikut:

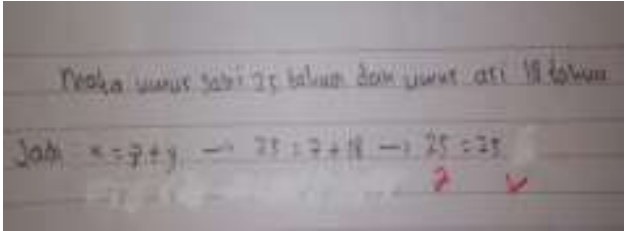

\section{Gambar 4. Jawaban S2 nomor 5 tahap 4}

Berdasarkan Gambar 4 dapat dilihat bahwa SM membuktikan bahwa jawaban yang diperoleh adalah benar dengan mengganti variabel dengan nilai yang telah didapatkan, namun masih belum lengkap. Dengan demikian SM sudah mengerjakan tahap 4 namun masih belum lengkap.

Dapat disimpulkan bahwa SM menyelesaikan soal nomor lima dengan 4 langkah Polya, namun pada tahap 2 dan 4 masih belum lengkap.

2. Peserta didik dengan tingkat kemampuan menengah.

a. Memahami masalah

Pada tahap ini Subjek 5 tidak melakukan langkah memahami masalah pada soal nomor dua, dan subjek 6 kurang teliti melakukan langkah ini pada soal nomor satu dan dua sehingga terdapat kesalahan dalam menentukan syarat cukup dan syarat perlu. b. Membuat rencana pemecahan masalah Pada tahap ini subjek 4 dan 5 tidak melakukan langkah merencanakan penyelesaian masalah dan subjek 6 melakukan langkah ini pada soal nomor tiga namun tidak lengkap dan rinci.

c. Melaksanakan rencana pemecahan masalah

Pada tahap ini subjek 4 dan 5 mampu melaksanakannya dengan benar dan tepat, namun pada soal nomor dua subjek 4 dan 5 tidak melakukan langkah ini. Subjek 5 juga terkendala pada soal nomor tiga. Subjek 6 tidak megerjakan langkah ini yaitu pada soal nomor dua, tiga dan lima.

d. Memeriksa kembali

Pada tahap ini banya subjek yang tidak menerapkannya.

Sebagai contoh subjek 7 pada soal nomor 6:

Sebuah toko kelontong menjual dua jenis beras sebanyak $50 \mathrm{~kg}$. Harga $1 \mathrm{~kg}$ beras jenis I adalah Rp 15.000 dan harga $1 \mathrm{~kg}$ jenis II adalah Rp 18.000. Jika harga beras seluruhnya Rp 792.000 maka tentukan berat beras jenis I dan berat beras jenis II yang dijual masing-masing! Dalam memahami masalah pada nomor dua dapat dilihat pada Gambar 5 


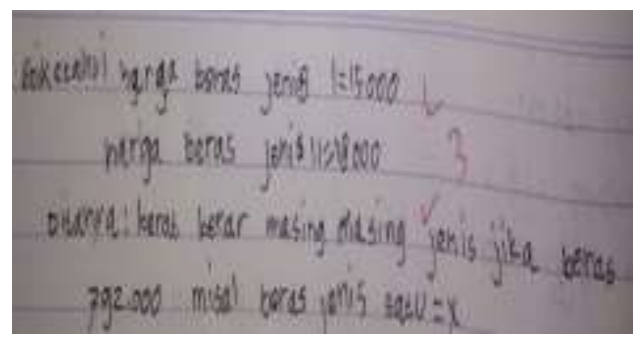

Gambar 5. Jawaban S6 nomor 6 tahap 1

Jika dilihat dari Gambar 5 pada tahap memahami masalah YP menuliskan apa yang diketahui dan apa yang ditanya pada soal. Dapat diketahui YP sudah mengerjakan tahap 1 dengan tepat.

Berdasarkan hasil tes YP menuliskan rencana penyelesaian soal nomor enam seperti Gambar 6 :

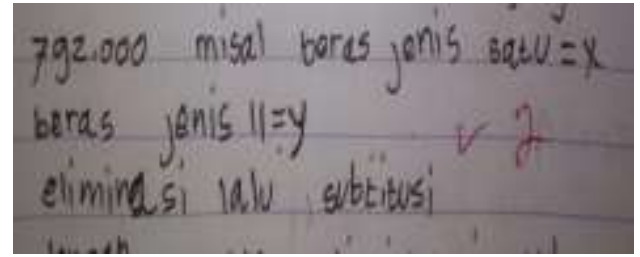

Gambar 6. Jawaban S6 nomor 6 tahap 2

Pada Gambar di atas dapat dilihat tahapan merencanakan masalah yang dilakukan YP memisalkan beras jenis I dan beras jenis II dengan variabel $\mathrm{x}$ dan variabel $\mathrm{y}$. Kemudian dilakukan langkah eliminasi, nilai variabel yang didapat dari hasil eliminasi disubtitusikan pada salah satu persamaan. Dengan demikian YP sudah mengerjakan tahap 2 .

Pada tahap penyelesaian dapat dilihat pada Gambar 7 .

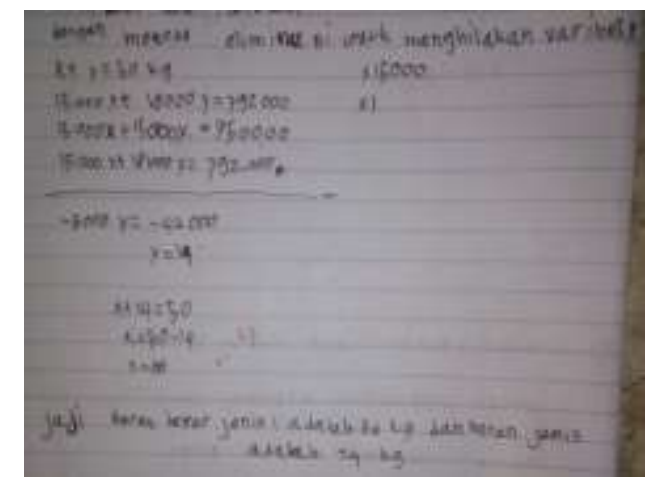

Gambar 7. Jawaban S6 nomor 6 tahap 3

Berdasarkan Gambar 7 dilakukan langkah eliminasi terlebih dahulu, kemudian nilai yang didapat disubtitusikan kepersamaan lain. Dengan demikian YP sudah mengerjakan tahap 3 dengan benar dan tepat.

Tahap pengecekan kembali dapat dilihat pada Gambar 8 .

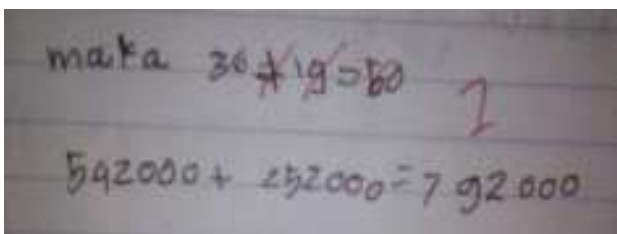

Gambar 8. Jawaban S6 nomor 6 tahap4

Berdasarkan Gambar di atas terdapat kesalahan pada $36+19=60$ yang seharusnya $36+14=50$, lebih jelas lagi jika ditulis:

$x+y=50 \mathrm{Kg} \rightarrow 36+14=50$

$36 \times 15.000=540.000$

$14 \times 18.000=\underline{252.000}+$ $50 \mathrm{Kg}=792.000$

Dengan demikian dapat ditentukan bahwa YP sudah mengerjakan tahap 4 namun masih ada kesalahan. Dengan demikian dapat disimpulkan bahwa YP 
mampu menyelesaikan soal nomor enam dengan 4 langkah Polya.

3. Peserta didik dengan tingkat kemampuan bawah.

a. Memahami masalah

Pada tahap ini subjek 7 dan subjek 8 subjek memiliki kecenderungan tidak mengalami kesulitan dalam menentukan kecukupan syarat yang diperlukan untuk menyelesaikan permasalahan.

b. Merencanakan penyelesaian masalah Pada tahap ini kedua subjek mengalami sedikit kesulitan menjelaskan hubungan antara yang diketahui dengan yang ditanya serta rencana langkah penyelesaian yang akan dilakukan.

e. Melaksanakan rencana pemecahan masalah

Pada tahap ini subjek tidak mampu menyelesaikan dengan langkah-langkah yang benar dan tepat.

c. Memeriksa kembali

Pada tahap ini subjek tidak mampu untuk memeriksa kembali jawaban mereka dengan menggunakan unsurunsur yang diketahui pada soal.

Sebagai contoh subjek 8 pada soal nomor 6:

Sebuah toko kelontong menjual dua jenis beras sebanyak $50 \mathrm{~kg}$. Harga $1 \mathrm{~kg}$ beras jenis I adalah Rp 15.000 dan harga $1 \mathrm{~kg}$ jenis II adalah Rp 18.000. Jika harga beras seluruhnya Rp 792.000 maka tentukan berat beras jenis I dan berat beras jenis II yang dijual masing-masing!

Berdasarkan hasil tes NAA menuliskan rencana penyelesaian soal nomor enam seperti Gambar 9:

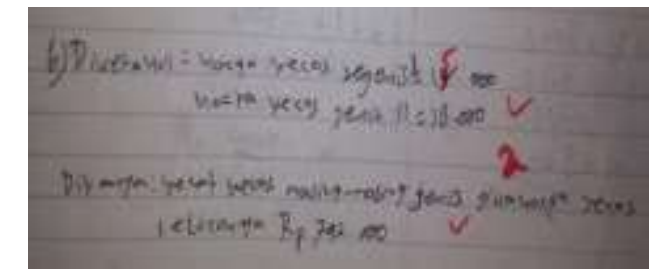

Gambar 9. Jawaban S8 nomor 6 tahap 1

Jika dilihat dari Gambar di atas pada tahap memahami masalah NAA menuliskan apa yang diketahui dan apa yang ditanya pada soal. Namun ada kesalahan pada harga beras jenis I menuliskan 19.000 yang seharusnya 15.000. Maka diketahui NAA sudah mengerjakan tajap 1 namun masih ada kesalahan.

Berdasarkan hasil tes NAA menuliskan rencana penyelesaian soal nomor enam seperti Gambar 10:

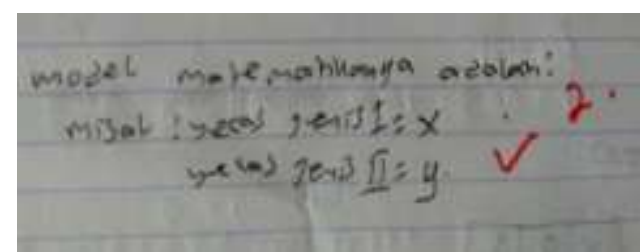

Gambar 10. Jawaban S8 nomor 6 tahap2

Pada Gambar di atas dapat dilihat tahapan merencanakan masalah yang dilakukan NAA memisalkan beras jenis I dan beras jenis II dengan variabel $\mathrm{x}$ dan variabel $\mathrm{y}$. Namun tidak menuliskan rencana selanjutnya yaitu langkah eliminasi, nilai variabel yang 
didapat dari hasil eliminasi disubtitusikan pada salah satu persamaan. NAA juga tidak menentukan persamaan satu dan persamaan dua. Dengan demikian NAA sudah mengerjakan tahap 2 namun belum lengkap.

Hasil penelitian ini senada dengan penelitian Devy Eganinta Tarigan (2012) dengan judul "Analisis Kemampuan Pemecahan Masalah Matematika Berdasarkan LangkahLangkah Polya Pada Materi Sistem Persamaan Linear Dua Variabel Bagi Siswa Kelas VIII SMP Negeri 9 Surakarta", bahwa kemampuan peserta didik yang berbeda memiliki karakteristik yang berbeda juga dalam memecahkan masalah.

Hal yang menonjol dari penelitian ini adalah sebelum dilakukan analisis berdasarkan langkah-langkah Polya, peserta didik terlebih dahulu diberikan perlakuan dengan menerapkan strategi pembelajaran problem solving. Selain itu, analisis yang dilakukan juga lebih detail pada jawaban hasil tes subjek penelitian. Penelitian ini lebih memperhatikan jawaban subjek penelitian disetiap langkah penyelesaian dengan cara membandingkan jawaban subjek dengan setiap tahapan pemecahan masalah Polya. Sehingga dapat diketahui lebih jelas dimana letak kekurangan masing-masing peserta didik dengan tingkat kemampuan yang berbeda dalam menyelesaikan soal berdasarkan langkahlangkah Polya.
Kemampuan pemecahan masalah dalam pembelajaran matematika sangat penting bagi peserta didik, diantaranya :

1. Kemampuan pemecahan masalah merupakan salah satu tujuan atau kompetensi yang akan dicapai dalam pembelajaran matematika.

2. pemecahan masalah sebagai tujuan dan proses, sehingga kemampuan pemecahan masalah yang diperoleh dalam suatu pembelajaran matematika pada umumnya dapat di transfer untuk digunakan dalam memecahkan masalah lain.

3. Pemecahan masalah adalah tipe belajar yang tingkatnya paling tinggi dan kompleks dibandingkan dengan tipe belajar lainnya.

4. Pemecahan masalah lebih mengutamakan proses dan strategi yang dilakukan peserta didik dalam penyelesaian masalah dari pada hanya sekedar hasilnya.

5. Pemecahan masalah matematika juga dapat meningkatkan kemampuan berfikir logis, kreatif dan sistematis.

Hal ini bertolak belakang dengan keadaan dilapangan. Banyak keragaman masalah yang berhubungan dengan kemampuan pemecahan masalah peserta didik. Hal ini membuat hasil belajar peserta didik menjadi rendah sehingga menjadi 
permasalahan yang terus dihadapi pendidik. Selain itu pendidik juga belum mengetahui bagaimana tingkat kemampuan pemecahan masalah peserta didik.

Mengingat betapa pentingnya kemampuan pemecahan masalah dalam pembelajaran matematika, dan starategi belajar yang cocok untuk diterapkan dalam pembelajaran maka perlu dilakukan analisa lebih mendalam terhadap kemampuan pemecahan masalah peserta didik. Penelitian ini dapat dijadikan sebagai informasi bagaimana tingkat kemampuan pemecahan masalah peserta didik, dan menjadi acuan untuk mencari solusi dalam meningkatkan kemampuan pemecahan masalah serta meningkatkan hasil belajar peserta didik.

\section{SIMPULAN DAN SARAN}

\section{Simpulan}

Berdasarkan analisis dan pembahasan yang dilakukan, dapat disimpulkan bahwa: Pada tahap memahami masalah sudah dilakukan peserta didik dengan baik, dengan menuliskan apa yang diketahui dan apa yang ditanyakan pada soal dengan persentase (89,68\%). Tahap menyusun rencana ini sudah dilakukan peserta didik dengan baik tetapi beberapa peserta didik dengan tingkat kemampuan rendah mengalami sedikit kesulitan pada tahap ini dengan persentase (89,88\%). Pada langkah melaksanakan rencana penyelesaian sudah dilakukan peserta didik, tetapi peserta didik berkemampuan menengah dan rendah masih mengalami kesulitan dengan persentase (66,52\%). Pada tahap mengecek kembali peserta didik dengan kemampuan tinggi sedikit mengalami kesulitan, sedangkan peserta didik dengan kemampuan menengah dan rendah tidak mampu melakukannya dengan persentase $(30,36 \%)$.

\section{Saran}

Berdasarkan kesimpulan penelitian di atas, maka penulis menyarankan beberapa hal sebagai berikut.

1. Bagi pendidik disekolah, sebagai informasi bagaimana kemampuan pemecahan masalah peserta didik, dan menjadi acuan untuk mencari solusi dalam meningkatkan kemampuan pemecahan masalah peserta didik.

2. Bagi peserta didik dapat menjadi motivasi untuk dapat terus meningkatkan kemampuan pemecahan masalahnya baik dalam pelajaran matematika maupun mata pelajaran lainnya.

3. Bagi peneliti lain, penelitian ini hanya ditunjukkan pada mata pelajaran matematika pada materi pokok semester ganjil yaitu sistem persamaan linear dua variabel, oleh karena itu sebaiknya penelitian juga dilakukan pada pokok materi matematika lainnya. 


\section{REFERENSI}

Agustina, Dina. 2014. Penerapan Strategi Pemecahan Masalah (Problem Solving) Untuk Meningkatkan Kemampuan Pemecahan Masalah Matematis Siswa Kelas VIII SMP Negeri 7 Padang. Vol 3 No 2 Edisi 2014.

Arikunto, Suharsimi. 2010. Dasar-dasar Evaluasi Pendidikan. Jakarta: Bumi Aksara.

Latif, Sriwahyuni. 2016. Mathematical Connection Ability In Solving Mathematics Problem Based On Initial Abilities of Students At SMPN 10 Bulukumba. Vol 4 No.2 Edisi 2 Juli 2016. Bulukumba.

Murdiana, I Nyoman. 2015. Pembelajaran Pemecahan Masalah Dalam Pembelajaran Matematika. Vol 4 No.1 Edisi Maret 2015.

Pristiwanto. 2016. Penerapan Metode Pemecahan Masalah (Problem Solving) Untuk Meningkatkan Pemahaman Siswa Tentang Komponen Peta. Vol 2 No. 2 Edisi Desember 2016. Lamongan

Riduwan. 2010. Skala Pengukuran Variabelvariabel Penelitian. Bandung: Alfabeta.

Sepriyanti, Nana. 2015. Pengaruh Model Pembelajaran Problem Based Learning Terhadap Kemampuan Pemahaman Konsep Pada Mata Kuliah Statistika Matematika I Mahasiswa Tadris Matematika IAIN Imam Bonjol
Padang. Vol 1 No.1 Edisi Maret 2015. Padang.

Sepriyanti, Nana. 2016. Pembelajaran Kalkulus Kontekstual Suatu Modifikasi Model. Jakarta : PT RajaGrafindo Persada.

Sepriyanti, Nana. 2017. Pengembangan Modul Matematika Berbasis Realistic Matematic Education pada Materi Sistem Pecrsamaan Linear. Vol 1 No.1 Edisi April 2017, pp 1-12. Padang.

Suherman, Erman dkk. 2003. Strategi Pembelajaran Matematika Kontemporer, Bandung JICA: Universitas Indonesia, 2003.

Sunaendar, Aep. 2017. Pembelajaran Matematika Dengan Pemecahan Masalah. Vol 2 No. 1 Edisi Juli 2017. Majalengka.

Tarigan, Devy Eganinta. 2012. "Analisis Kemampuan Pemecahan Masalah Matematika Berdasarkan LangkahLangkah Polya Pada Materi Sistem Persamaan Linear Dua Variabel Bagi Siswa Kelas VIII SMP Negeri 9 Surakarta Ditinjau Dari Kemampuan Penalaran Siswa". Surakarta: Universitas Sebelas Maret Surakarta.

Ulpa, Zulpia. 2014. “Menyelesaikan Soal Cerita Sistem Analisis Proses Berpikir Siswa Yang Mempunyai Kecerdasan Visual Spasial Dalam Persamaan Linear Dua Variabel Di Kelas VIII SMP N 1 Muaro Jambi". Vol 8 No. 1 Edisi 2014. Jambi 